\title{
The occurrence of a bloom-forming green alga Pleodorina indica (Volvocales) in the downstream reach of the River Malse (Czech Republic)
}

\author{
Petr Znachor ${ }^{1, *} \&$ Jitka Jezberova ${ }^{1,2}$ \\ ${ }^{1}$ Hydrobiological Institute ASCR, 37005 České Budějovice, Czech Republic \\ ${ }^{2}$ Faculty of Biological Sciences, University of South Bohemia, 37005 České Budéjovice, Czech Republic \\ (*Author for correspondence: Tel.: +420-387-775-884, Fax: +420-385-310248,E-mail: znachy@hbu.cas.cz) \\ Received 24 May 2004; in revised form 15 October 2004; accepted 29 October 2004
}

Key words: bloom, diurnal changes, green algae, Pleodorina indica, river, scums

\begin{abstract}
In mid-August 2003 a massive bloom of the green alga Pleodorina indica (Iyengar) Nozaki (Volvocales) occurred in the downstream reach of the River Malše in the Czech Republic. An exceptionally long period of the hot dry weather resulted in low flow conditions and warm water temperatures. These environmental conditions combined with high nutrient concentrations led to the macroscopic appearance of $P$. indica in the form of an extensive surface scum formation with diurnal changes. The alga soon dominated the river phytoplankton, attaining concentrations of 2000 colonies per millilitre. The bloom persisted in the river from the 10-17 August when it was eventually flushed out. $P$. indica is an indigenous species of tropical climatic regions and prior to this its massive occurrence has not been reported in the temperate region of Central Europe.
\end{abstract}

\section{Introduction}

Algae and cyanobacteria are commonly involved in a variety of biological processes that influence river water quality. When rivers host an increased growth of planktonic algae or cyanobacteria and such proliferation is dominated by a single (or a few) species, the phenomenon is referred to as an algal or cyanobacterial bloom (Chorus \& Bartram, 1999). Mostly cyanobacterial blooms have been studied due to their potential toxin production (Sherman et al., 1998; Mitrovic et al., 2001), however algal blooms were also referred (Roos \& Pieterse, 1996). Such an excessive growth of algae dramatically impairs water quality and, as the accumulated biomass is being decomposed by microorganisms, a serious oxygen depletion results that is often fatal to sensitive organisms.

Flagellated green algae are found in a variety of differing aquatic habitats. Some species tend to form blooms primarily in semi-permanent rain pools (Al-Homaidan \& Arif, 1998; Desnitski, 2000). In such environments their life cycle provides for rapid colonisation and further growth (Desnitski, 2000, 2002). Cultivated Pleodorina strains have been the subjects of numerous molecular, morphological and phylogenetic analyses (e.g., Nozaki, 1996; Nozaki et al., 1997, 1999; Angeler et al., 1999; Coleman, 2002; Nozaki, 2003a). Further, Desnitski (2003) reviewed the geographical distribution and morphology of Pleodorina in detail. Yet in all these studies of Pleodorina, the ecology of the different species was not addressed.

$P$. indica (Iyengar) Nozaki, which flourished in the River Malše is an indigenous species of tropical climates and prior to the Czech Republic bloom, it had not been reported in the temperate regions of Central Europe. The objective of this paper is: (1) to document the first known occurrence of this thermophilic green alga within the temperate regions of Central Europe and review its geographical distribution and (2) to describe the 
particular ecological factors which resulted in the massive bloom of $P$. indica.

\section{Materials and methods}

Study site description

The River Malše is a shallow, eutrophic river originating in Austria (Maltsch) and flowing through the southern part of the Czech Republic in Central Europe. Approximately $40 \%$ of the catchment area $\left(961 \mathrm{~km}^{2}\right)$ is covered by agricultural lands and forests. After traversing a distance of $89.5 \mathrm{~km}$ it converges from the east with the River Vltava in the city of Česke Budějovice at an altitude of $385 \mathrm{~m}$ a.s.l. At the confluence the river channel is $30 \mathrm{~m}$ wide and $3 \mathrm{~m}$ deep. It has been artificially confined by means of canals, which have sparse shoreline vegetation. The long-term mean discharge is $7 \mathrm{~m}^{3} \mathrm{~s}^{-1}$. Downstream of the confluence is a manmade weir that impedes flows and impounds water for a distance of $1.5 \mathrm{~km}$ up the River Malše. This area, with its 'stagnant water' appearance, was the study site.

\section{Sampling and methods}

In mid-August 2003, three sets of samples were collected from the surface at three separate sampling sites $(\mathrm{A}-\mathrm{C})$ along a longitudinal profile of the downstream reach of the River Malše (Fig. 1). Duplicated samples were taken from the shore. Diurnal changes were observed on two-hour intervals from 6 a.m. to 10 p.m. for three consecutive days (August 13-15). Water temperature and pH were measured in situ with a WTW 330i m. All chemical and biological parameters were laboratory analyzed immediately after sampling.

Samples of phytoplankton for biomass estimation were preserved with Lugol solution. Phytoplankton species were enumerated using the Utermohl sedimentation method on an inverted microscope (Olympus IMT-2, Lund et al., 1958). The mean cell dimensions were obtained for biovolume calculation using the approximation of cell to geometrical solids. Biovolume was converted into fresh mass (FM) assuming the specific density of phytoplankton to be equal $1 \mathrm{mg} \mathrm{mm}^{-3}$ (Rott,

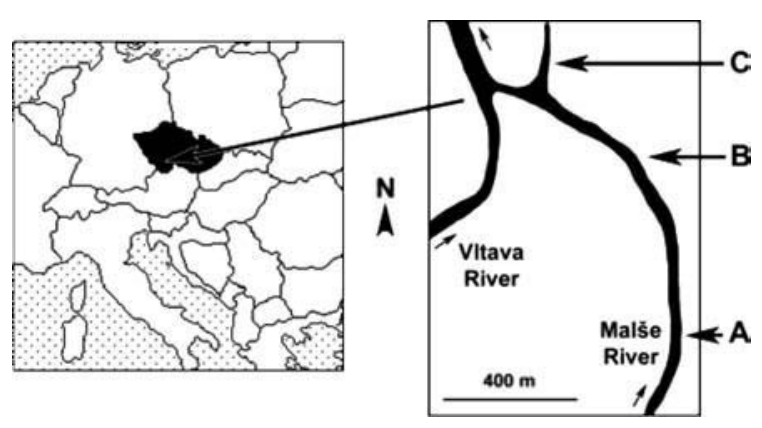

Figure 1. Map of the locality studied. Sampling sites are denoted by capital letters.

1981). Microphotographs were taken from the Olympus BX 51 microscope with an Olympus DP 70 digital camera using Nomarski differential interference contrast technique.

Total phosphorus (TP) and soluble reactive phosphorus (SRP) were analyzed spectrophotometrically according to Kopaček \& Hejzlar (1993) and Murphy \& Riley (1962), respectively. The concentration of $\mathrm{NH}_{4}^{+}$and $\mathrm{NO}_{3}^{-}$was determined following the procedure of Kopaček \& Prochazkova (1993) and Prochazkova (1959), respectively. River discharge data were provided by the River Vltava authority, as measured at an upstream gauging station. Data on air temperature and rainfall were obtained from the Czech Institute of Hydrometeorology.

\section{Results}

On August 11, 2003 we observed a massive bloom of green alga $P$. indica in the downstream reach of the River Malše that had already been reported the previous day. The formation of dense surface scums containing high cell density accumulated during the period that the phenomenon was being studied. At some locales scums of a foam-like consistency covered the surface of the entire river channel (Fig. 2(A, B)). The bloom persisted for 8 days until it was washed out by the flow.

\section{Weather conditions}

The summer of 2003 was characterized by extremely high temperatures and low rainfall in the Czech Republic. During July and August, the 

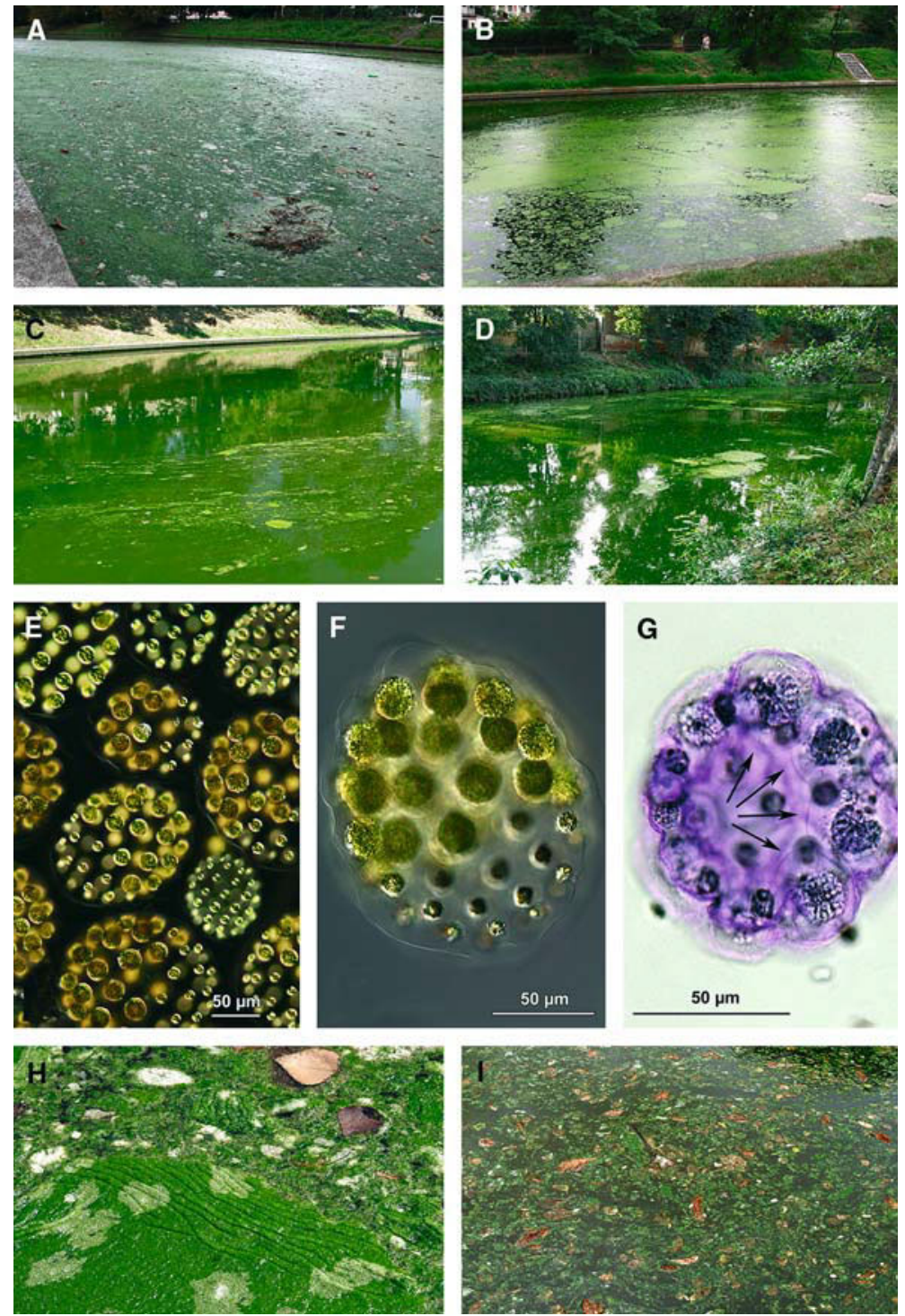

Figure 2. Accumulated colonies of $P$. indica formed scums in the River Malše (A, B). The dense scums redispersed into optically homogenous suspension (C, D). Microscopic view on the cenobial colonies of $P$. indica with differentiated somatic and reproductive cells $(\mathrm{E}, \mathrm{F})$. The colony is enclosed in gelatinous matrix, individual sheaths (indicated by arrows) are highlighted after methylene blue staining $(G)$. Detail view on the mats of foam-like consistence, which were saturated by gas bubbles $(\mathrm{H})$. Transition state before or after the aggregation into the macroscopic scum (I).

monthly average temperature was 2 and $4{ }^{\circ} \mathrm{C}$ higher, respectively than normal. Clear skies allowed for daily temperatures exceeding $30^{\circ} \mathrm{C}$, which prevailed over the period of algal bloom in the River Malše. On August 13, a record was set for that date of $36.8{ }^{\circ} \mathrm{C}$, measured at a station located near the study locality. The heat, combined with low precipitation resulted in minimal discharge in the River Malše, approximately four times lower than the long-term average (long-term August average flow $6.2 \mathrm{~m}^{-3} \mathrm{~s}^{-1}$ ). This discharge of only $1.3 \mathrm{~m}^{-3} \mathrm{~s}^{-1}$ was stable during the period studied. The only exception was measured on August 14, when the discharge temporarily rose to $1.6 \mathrm{~m}^{-3} \mathrm{~s}^{-1}$. This lasted only $18 \mathrm{~h}$ and then the flow rapidly dropped to its previous values. 


\section{Physical and chemical parameters of the river}

Water temperatures ranged between 23 and $26{ }^{\circ} \mathrm{C}$ (Table 1), reflecting the warmer than normal air temperatures. The highest temperatures were measured at sampling sites B and C on August 12 (Table 1) and a temperature of $23{ }^{\circ} \mathrm{C}$ was recorded at site A. On August 15 the temperatures decreased to $23{ }^{\circ} \mathrm{C}$ at all sampling sites. Particularly at the beginning of the period studied, a high $\mathrm{pH}$ was measured at all sampling sites following the same pattern as water temperature (Table 1). High concentrations of both TP and SRP were also found (Table 1). Ammonia ion concentration ranged from 0.3 to $0.6 \mathrm{mg}^{-1}$, however, nitrate nitrogen was occasionally depleted to undetectable levels (Table 1).

\section{The biomass of $\mathrm{P}$. indica}

On August 12 an overwhelming dominance of $P$. indica was recorded at the uppermost sampling sites, A and B (Fig. 3, Table 2). While the accumulated biomass formed dense surface scums at site $\mathrm{A}$, the biomass was largely dispersed at site $\mathrm{B}$ (Fig. 2(C) and (D)). At site C colonial cyanobacteria (Microcystis viridis, $M$. aeruginosa) dominated the phytoplankton with $P$. indica accounting for only $3 \%$ of the total biomass (Fig. 3).

$P$. indica remained the dominant species at site A, but by August 15 there was an apparent decrease in the biomass. A reverse, upstream flow induced by the confluence of the Malse and Vltava

Table 1. Physical and chemical parameters measured in longitudinal profile of the River Malse

\begin{tabular}{|c|c|c|c|c|c|c|}
\hline & \multicolumn{2}{|l|}{ Site A } & \multicolumn{2}{|l|}{ Site B } & \multicolumn{2}{|l|}{ Site C } \\
\hline & 12-Aug & 15-Aug & 12-Aug & 15-Aug & 12-Aug & 15-Aug \\
\hline $\begin{array}{l}\text { Water } \\
\text { temperature }\left({ }^{\circ} \mathrm{C}\right)\end{array}$ & 23 & 22.5 & 25.6 & 23.2 & 25.3 & 23.3 \\
\hline $\mathrm{pH}$ & 8.1 & 7.6 & 9.5 & 8.2 & 8.9 & 8.3 \\
\hline $\mathrm{NH}_{4}^{+}\left(\mathrm{mg} \mathrm{l}^{-1}\right)$ & 0.6 & 0.4 & 0.3 & 0.4 & 0.4 & 0.3 \\
\hline $\mathrm{NO}_{3}^{-}\left(\mathrm{mg} \mathrm{l}^{-1}\right)$ & b.d.1. & 0.6 & 0.6 & 0.8 & 0.3 & 0.3 \\
\hline $\mathrm{TP}\left(\mu \mathrm{g}^{-1}\right)$ & 233 & 146 & 91 & 103 & 53 & 117 \\
\hline $\mathrm{SRP}\left(\mu \mathrm{g} \mathrm{1^{-1 }}\right)$ & n.a. ${ }^{+}$ & 36 & n.a. ${ }^{+}$ & 24 & n.a. ${ }^{+}$ & 33 \\
\hline
\end{tabular}

\footnotetext{
* Beyond detection limit.
}

+ Not available.
Rivers caused a translocation of phytoplankton biomass between sites B and C (Fig. 3).

By August 17 the situation on the river changed considerably. The most frequent algal species found in the phytoplankton at sites A and B were small centric diatoms (Stephanodiscus sp.), cryptophytes (Cryptomonas reflexa Skuja, C. marssonii Skuja), cyanobacteria (M. viridis (A. Br. in Rabenh.) Lemm., $M$. aeruginosa Kutz.) and a variety of green algae (Scenedesmus sp., Tetraedron sp., Pediastrum duplex Meyen). $P$. indica had vanished from both upstream sites. Dense surface scums were recorded only at site $\mathrm{C}$, where the maximum value of $P$. indica biomass was measured (Fig. 3). The accumulated biomass subsequently washed out of the study locality. An increase of discharge measured on August 14 appeared to initiate the flushing of the algal biomass downstream. Downstream of the confluence the accumulated biomass of $P$. indica was likely dispersed by the combined flows of the two rivers and subsequently died out.

\section{Diurnal changes}

Diurnal changes in the macroscopic appearance of the bloom were recorded on 2-h intervals. Daytime formation of dense scums having a foam-like consistency was observed. At certain river areas these scums or foams occasionally covered the entire river surface. Over the night the scums would disintegrate and in the morning the colonies were redispersed into an optically homogenous suspension. This cycle recurred for several consecutive days until the bloom washed downstream and dispersed.

\section{Morphology of $\mathrm{P}$. indica}

$P$. indica is a coenobic colonial green alga assigned to the order Volvocales. Spherical, ovoid or ellipsoidal colonies (Fig. 2(E) and (F)) of 128 or 64 or 32 cells are arranged radially at the periphery of a gelatinous matrix (up to $300 \mu \mathrm{m}$ long). Observed cells were spherical or ellipsoidal, each with two equal flagella, a stigma, many contractile vacuoles on the cell surface, and a massive cup-shaped chloroplast with single or multiple pyrenoid (Nozaki, 2003b). The anterior $1 / 5-1 / 3$ of the cells in a colony were small, nearly spherical (up to $16 \mu \mathrm{m}$ 
Site A

Site B

Site C

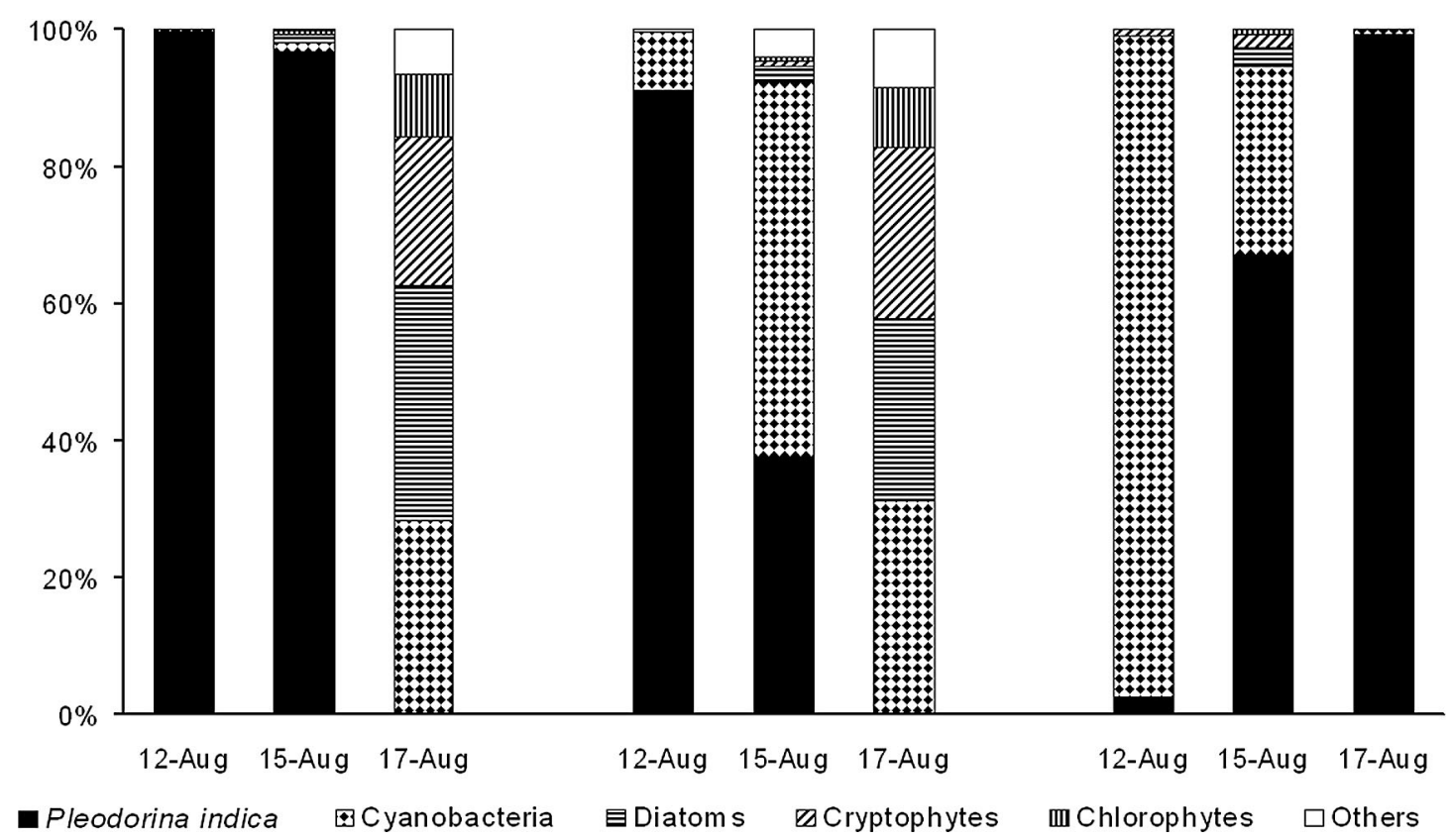

Figure 3. Algal and cyanobacterial composition of phytoplankton in longitudinal profile of the downstream reach of the River Malse.

in diameter) and obligately somatic. Remaining reproductive cells gradually increased in cell size from anterior to posterior pole reaching up to $25 \mu \mathrm{m}$ in diameter. Gelatinous matrix formed individual sheaths, which were highlighted after staining with diluted methylene blue (Nozaki et al., 1989, Fig. 2(G)). The presence of individual sheaths was the main taxonomic feature that dis-

Table 2. Changes of biomass (FM, $\mathrm{mg}^{-1}$ ) and abundance $\left(10^{3}\right.$ cells $\left.\mathrm{ml}^{-1}\right)$ of $P$. indica in longitudinal profile of the River Malse

\begin{tabular}{|c|c|c|c|c|c|c|}
\hline \multirow{2}{*}{$\begin{array}{l}\text { Date of } \\
\text { sampling }\end{array}$} & \multicolumn{2}{|c|}{ Site A } & \multicolumn{2}{|c|}{ Site B } & \multicolumn{2}{|c|}{ Site C } \\
\hline & FM & $\begin{array}{l}\text { Cell } \\
\text { No }\end{array}$ & FM & $\begin{array}{l}\text { Cell } \\
\text { No }\end{array}$ & $\mathrm{FM}$ & $\begin{array}{l}\text { Cell } \\
\text { No }\end{array}$ \\
\hline August 12 & 268 & 145.4 & 30 & 18.5 & 0.4 & 0.2 \\
\hline August 15 & 71 & 44.6 & 3.4 & 1.2 & 10.2 & 5.4 \\
\hline August 17 & 0 & 0 & 0 & 0 & 266 & 140.5 \\
\hline
\end{tabular}

tinguished $P$. indica from other species of the genus Pleodorina.

\section{Discussion}

Geographical distribution of the species of the genus Pleodorina

Pleodorina is cosmopolitan in freshwaters and includes four species (Nozaki et al., 1989). $P$. japonica Nozaki was collected by Nozaki et al. (1989) from the immersed water near the bottom of rice plants in a paddy field (Japan). The authors reported only sparse presence of vegetative colonies of this taxon. Another species of Pleodorina, $P$. californica Shaw, appeared to occur abundantly but at a limited number of localities in the USA (Smith, 1916; Nozaki, 2003b; Coleman personal communication). According to Ettl (1983), P. indica (originally described as Eudorina indica Iyengar) is an endemic species, which is found only in 
semi-permanent rainfall marshes in Mysore Province and also in the surroundings of Madras (both in India). However, this assumption was contradicted by later findings where $P$. indica was identified in Mexico and studied by light and electron microscopy (Nozaki et al., 1989; Nozaki \& Kuroiwa, 1992). Also, according to Zalocar (1993), P. indica occurs in South America (Argentina). Moreover, Angeler et al. (1999) and Coleman (2002), in their studies of phylogenetic relationship among isolates of Eudorina and Pleodorina species, analyzed a $P$. indica strain (ASW05153), which originates from culture collection of algae at the University of Vienna (Austria, Central Europe). The strain was isolated from eutrophic backwater of the River Danube (locality Gießgang Greifenstein, Lower Austria) in July 1996. In contrast with massive occurrence of $P$. indica in the River Malše, it occurred sparsely in low abundance among a variety of other algal species and did not dominate the phytoplankton (Schagerl, personal communication). To date, $P$. sphaerica Iyengar appears to be the only endemic species that is found solely in India (Iyengar, 1933; Ettl, 1983; Desnitski, 2003). Unspecified Pleodorina was found near Cape Maclear in the phytoplankton of southern Lake Malawi (Haberyan \& Mhone, 1991), however, it accounted for only $10 \%$ of total algal biomass. Al-Homaidan \& Arif (1998), in their study of the ecology of algae in semi-permanent rain-fed pools in Saudi Arabia, observed that certain green flagellates (Carteria multifilis (Fresenius) Dill, Chlamydomonas sp.) do occasionally form water blooms.

Basically, there are two possible options clarifying the remarkable occurrence of $P$. indica in Central Europe. Besides tropical regions, $P$. indica may occur naturally also in temperate zone but only in very low abundance or at sparse number of localities. This would elucidate the lack of records regarding the occurrence of this green alga in the Czech Republic. The other options is an introduction, however, the method of introduction of $P$. indica in the River Malše is disputable. We hypothesize that $P$. indica might have been brought to the Czech Republic by waterfowl migrating from southern regions hospitable to the alga. Nonetheless, accidental human contamination of the waterway with this alga also can not be ruled out. There are a few documented incidents where a rapid spread of a prominent species in a river system was attributable to accidental introduction or environmental changes (Talling \& Lemoalle, 1998). In the August 2003 case in the River Malše, it was evident that $P$. indica was an indigenous species of warm climates and, as far we know, the bloom of this green alga has never been recorded in the temperate region of Central Europe. A parallel might be found in the geographical distribution of the invasive cyanobacterium Cylindrospermopsis raciborskii (Neilan et al., 2003). This species, which was originally described as a taxon of only tropical interests, has been now reported from temperate regions of Australia, Europe and America (e.g., Padisak,1997). Presently, the massive occurrence of $P$. indica in the Czech Republic is considered a unique, exceptional event rather than a common feature of future phytoplankton development.

\section{Diurnal changes}

Diurnal changes in macroscopic appearance of the bloom were recorded. During the day the formation of a dense scum was observed, while over night the scums disintegrated and colonies redispersed into an optically homogenous suspension. Since $P$. indica is a flagellated green alga, active regulation of the vertical position in the water column is to be expected (Clegg et al., 2003). Therefore, the following explanation is proposed. The aggregated colonies formed foam-like scums saturated with oxygen bubbles evolved by the photosynthetic process. Once trapped on the surface, the colonies were not able to regulate their position in the water column and subsequent photodestruction resulted in partial scum discoloration (Fig. 2(H)). During the night the bubbles were either released into the atmosphere or the excessive oxygen diffused into the water and the colonies dispersed into the water (Fig. 2(I)). Each morning the photosynthetic production of oxygen prevailed over respiration and the whole cycle recurred. The proposed mechanism is based on repeated observation, however, the lack of detailed information impeded clarification of the mechanism involved in the aggregation process. Kobližek et al. (2002) concluded that the aggregation of unicellular cyanobacterium Synechococcus represented the light-adaptive mechanism affected by 
irradiance. Light is assumed to be the driving force of algal vertical migrations (Clegg et al., 2003) and it might be also the prime impulse in the aggregation of $P$. indica colonies.

\section{Causes of the bloom}

It could be questioned as to why the occurrence of $P$. indica was restricted only to the downstream reach of the River Malše. The analyses of samples which were taken from an upstream reach of the river at the same time, only revealed the presence of low abundant common species of coenobial volvocalean algae (Pandorina morum (O. F. Muller) Bory, Eudorina elegans Ehrenb., Gonium sp.). P. indica was not found at all. The environmental conditions in the turbulent upstream reach of the River Malše appeared to preclude the growth and maintenance of this planktonic green alga. Nevertheless, the lowflowing artificially constrained river channel in the downstream reach exhibited a transitional habitat between the lotic and lentic systems. The lower flow permitted a greater retention time for planktonic algae, which in turn, enhanced biomass populations in a nutrient rich environment. Although not measured, the establishment of temporary thermal stratification at the sampling sites is assumed. According to Sherman et al. (1998), the establishment of persistent thermal stratification is a major factor in nurturing the phytoplankton species composition of a river. Additionally, high nutrient concentrations would also have been a factor contributing to the bloom of $P$. indica. High measured concentrations of both TP and SRP (Table 1) indicated that the growth of $P$. indica was not phosphorus limited. Exceptionally low concentrations of nitrate nitrogen (Site A, August 12, Table 1) were a probable result of the extensive nitrogen consumption by this alga.

The bloom of $P$. indica in the River Malše was likely triggered by the anomalous tropical weather conditions, resulting in minimal rainfall and low river discharge. It is not known whether the flourishing of this thermophilic species is an indication of the global warming phenomenon, however, this is the first record of the any massive occurrence of $P$. indica in the region of Central Europe.

\section{Acknowledgements}

This study was supported by Project No. S6017004, "Water quality control in reservoirs," and by EU environment Project No. EVK2-199900213, 'MIDI-CHIP'. The authors also wish to acknowledge and thank J. Komarkova, T. Fea, A. Coleman, A Desnitski and H. Nozaki for their assistance and greatly useful advice.

\section{References}

Al-Homaidan, A. A. \& I. A. Arif, 1998. Ecology and bloomforming algae of a semi-permanent rain-fed pool at Al-Kharj, Saudi Arabia. Journal of Arid Environements 38: 15-25.

Angeler, D. G., M. Schagerl \& A. W. Coleman, 1999. Phylogenetic relationships among isolates of Eudorina species (Volvocales, Chlorophyta) inferred from molecular and biochemical data. Journal of Phycology 35: 815-823.

Chorus, I. \& J. Bartram, 1999. Toxic Cyanobacteria in Water. A guide to their public health, consequences, monitoring and management. E and FN Spon, London and New York, 416 pp.

Clegg, M. R., S. C. Maberlyand \& R. I. Jones, 2003. The effect of photon irradiance on the behavioral ecology and potential niche separation of freshwater phytoplanktonic flagellates. Journal of Phycology 39: 650-662.

Coleman, A. W., 2002. Comparison of Eudorina/Pleodorina ITS sequences of isolates from nature with those from experimental hybrids. American Journal of Botany 89: 1523-1530.

Desnitski, A., 2000. Development and reproduction of two species of the genus Volvox in a shalow temporary pool. Protistology 1: 195-208.

Desnitski, A., 2002. Dormant stages of the green flagellate Volvox in a natural habitat. Russian Journal Developmental Biology 33: 107-109.

Desnitski, A., 2003. A review on green microalgae of the genus Pleodorina (in Russian with English summary). Vestnik Sankt-Peterburgskogo Universiteta 3: 98-102.

Ettl, H., 1983. Chlorophyta I. Phytomonadina. In Ettl, H., J. Gerloff \& D. Mollenhauer (eds), Su $\beta$ wasserflora von Mitteleuropa, Bd. 9., Gustav Fischer Verlag, Stuttgart, 807 pp.

Haberyan, K. A. \& O. K. Mhone, 1991. Algal communities near Cape Maclear, southern Lake Malawi, Africa. Hydrobiologia 215: 175-188.

Iyengar, M. O. P., 1933. Contribution to our knowledge of the colonial Volvocales from India. Journal of the Linnean Society. Botany 49: 323-372.

Koblıžek, M., J. Komenda, J. Masojidek \& L. Pechar, 2000. Cell aggregation of the cyanobacterium Synechococcus elongatus: role of the electron transport chain. Journal of Phycology 36: 662-668.

Kopaček, J. \& J. Hejzlar, 1993. Semi-micro determination of total phosphorus in fresh waters with perchloric acid 
digestion. International Journal of Environmental Analytical Chemistry 53: 173-183.

Kopacek, J. \& L. Prochazkova, 1993. Semi-micro determination of ammonia in water by the rubazoic acid method. International Journal of Environmental Analytical Chemistry 53: 243-248.

Lund, J. W. G., C. Kipling \& E. D. Le Cren, 1958. The inverted microscope method of estimating algal numbers and the statistical basis of estimation by counting. Hydrobiologia 11: 14-70.

Mitrovic, S. H., L. C. Bowling \& R. T. Buckney, 2001. Responses of phytoplankton to in-situ nutrient enrichment: potential influences on species dominance in a river. International Review of Hydrobiology 86: 285-298.

Murphy, J. \& J. P. Riley, 1962. A modified single-solution method for the determination of phosphate in natural waters. Analytica Chimica Acta 27: 31-36.

Neilan, B. A., M. L. Saker, J. Fastner, A. Torokne \& B. P. Burns, 2003. Phylogeography of the invasive cyanobacterium Cylindrospermopsis raciborskii. Molecular Ecology 12: $133-140$.

Nozaki, H., 1996. Morphology and evolution of sexual reproduction in the Volvocaceae (Chlorophyta). Journal of Plankton Research 109: 353-361.

Nozaki, H., 2003a. Origin and evolution of the genera Pleodorina and Volvox (Volvocales). Biologia 58: 425-431.

Nozaki, H., 2003b. Flagellated green algae. - In Wehr J. D. \& R. G. Sheath (eds), Freshwater algae of North America. Academic Press, Amsterdam, Boston, London, New York, Oxford, Paris, San Diego, Singapore, Sydney, Tokyo: 225-252.

Nozaki, H., M. Ito, H. Uchida, M. M. Watanabe \& T. Kuroiwa, 1997. Phylogenetic analysis of Eudorina species (Volvocaceae, Chlorophyta) based on rbcL gene sequences. Journal of Phycology 33: 859-863.

Nozaki, H. \& T. Kuroiwa, 1992. Ultrastucture of the extracellular matrix and taxonomy of Eudorina, Pleodorina and
Yamagishiella gen. nov. (Volvocaceae, Chlorophyta). Phycologia 31: 529-541.

Nozaki, H., H. Kuroiwa, T. Mita \& T. Kuroiwa, 1989. Pleodorina japonica sp. nov. (Volvocales, Chlorophyta) with bacteria-like endosymbionts. Phycologia 28: 252-267.

Nozaki, H., N. Ohta, H. Takano \& M. M. Watanabe, 1999. Reexamination of phylogenetic relationships within the colonial Volvocales (Chlorophyta): an analysis of atpB and $\mathrm{rbcL}$ gene sequences. Journal of Phycology 35: 104-112.

Padisak, J., 1997. Cylindrospermopsis raciborskii (Woloszynska) Seenayya et Subba Raju, an expanding, highly adaptive cyanobacterium: worldwide distribution and review of its ecology. Archiv fur Hydrobiologie 107: 563-593.

Prochazkova, L. 1959. Bestimmung der Nitrate im Wasser. Zeitschrit fur Analytische Chemie 167: 254-260.

Roos, J. C. \& A. J. H. Pieterse, 1996. Seasonal variation of phytoplankton biomass in the Middle Vaal River, South Africa. Water SA 22: 33-42.

Rott, E. 1981. Some results from phytoplankton counting intercalibrations. Zeitschrift fur Hydrologie 43: 34-62.

Sherman, B. S., I. T. Webster, G. J. Jones \& R. L. Oliver, 1998. Transition between Aulacoseira and Anabaena dominance in a turbid river weir pool. Limnology And Oceanography 43: 1902-1915.

Smith, B. G., 1916. Notes on Pleodorina californica Shaw. Eighteenth Annual Report of the Michigan Academy of Science 1916: 99-101.

Talling, J. F. \& J. Lemoalle, 1998. Ecological dynamics of tropical inland waters. Cambridge University Press, Cambridge, $441 \mathrm{pp}$.

Zalocar, Y., 1993. Volvocales coloniales (Chlorophyta) del nordeste Argentino. Folia Bot. et Geobot. Correntesiana (Herbarium Humboldtianum, Universidad Nacional del Nordeste, Gorrientes, Argentina) 9: 1-18. 